\title{
Optical and nonoptical aids for reading and writing in individuals with acquired low vision
}

\author{
Auxílios ópticos e não ópticos na leitura e escrita de pessoas com baixa visão adquirida
}

\author{
Mayla Myrina Bianchim Monteiro ${ }^{1}$, Rita de Cássia Ietto Montilla ${ }^{1}$, Keila Miriam Monteiro de Carvalho¹, Maria Elisabete Rodrigues Freire Gasparetto ${ }^{1}$
}

\begin{abstract}
Purpose: To evaluate the use of optical and nonoptical aids during reading and writing activities in individuals with acquired low vision.

Methods: This study was performed using descriptive and cross-sectional surveys. The data collection instrument was created with structured questions that were developed from an exploratory study and a previous test based on interviews, and it evaluated the following variables: personal characteristics, use of optical and nonoptical aids, and activities that required the use of optical and nonoptical aids. Results: The study population included 30 subjects with acquired low vision and visual acuities of 20/200-20/400. Most subjects reported the use of some optica aids (60.0\%). Of these $60.0 \%$, the majority (83.3\%) cited spectacles as the most widely used optical aid. The majority $(63.3 \%)$ of subjects also reported the use of nonoptical aids, the most frequent ones being letter magnification (68.4\%), followed by bringing the objects closer to the eyes (57.8\%). Subjects often used more than one nonoptical aid.

Conclusions: The majority of participants reported the use of optical and nonoptical aids during reading activities, highlighting the use of spectacles, magnifying glasses, and letter magnification; however, even after the use of these aids, we found that the subjects often needed to read the text more than once to understand it. During writing activities, all subjects reported the use of optical aids, while most stated that they did not use nonoptical aids for such activities.
\end{abstract}

Keywords: Vision, low/rehabilitation; Reading; Visually impaired individuals; Language; Handwriting; Audiovisual aids

\section{RESUMO}

Objetivo: Avaliar o uso de auxílios ópticos e não ópticos na leitura e na escrita de pessoas com baixa visão adquirida.

Métodos: Realizou-se estudo descritivo, tipo transversal. O instrumento de coleta de dados continha questões estruturadas, desenvolvidas em estudo exploratório e teste prévio e foi aplicado por entrevista, onde foram investigadas as seguintes variáveis: características pessoais, uso de auxílios ópticos e não ópticos, atividades para as quais utiliza auxílios ópticos e não ópticos.

Resultados: A população foi composta por 30 sujeitos com baixa visão adquirida, com acuidade visual entre 20/200 a 20/400. A maioria dos sujeitos declarou fazer uso de algum tipo de auxílio óptico (60,0\%). Desses 60,0\%, a maioria (83,3\%) citou os óculos como o auxílio óptico mais usado. A maioria $(63,3 \%)$ dos sujeitos relatou fazer uso de auxílios não ópticos e os mais citados foram a ampliação de letras (68,4\%), sequidos da aproximação dos objetos aos olhos (57,8\%). Os sujeitos ressaltaram o uso de mais de um auxílio não óptico.

Conclusão: A maioria informou utilizar os auxílios ópticos enão ópticos nas atividades de leitura, evidenciando o uso de óculos e da lupa manual, assim como da ampliação de letras, mas mesmo utilizando tais auxílios verificou-se que os sujeitos necessitavam ler o texto mais de uma vez para terem a compreensão do mesmo. Para a realização das atividades de escrita, a totalidade dos sujeitos declarou utilizar os auxílios ópticos, enquanto que a maioria declarou não utilizar auxílios não ópticos nessas atividades.

Descritores: Baixa visão/reabilitação; Leitura; Pessoas com deficiência visual; Linguagem; Escrita manual; Recursos audiovisuais

\section{INTRODUCTION}

Vision plays an important role in human development because it stimulates and directs human movements and actions. It is the agent's motivation to trigger the acquisition of skills, and it allows capture of the environment quickly and efficiently. Vision is the sense that rapidly unifies sensations (tactile and auditory) and sets a direction in relation to the other part ${ }^{(1)}$.

The relationship with the outside world is accomplished primarily through vision; therefore, ocular problems can cause serious adverse effects on learning and socialization (2).

According to the 10th Revision of the International Classification of Diseases and Related Health Problems (ICD-10) by the World Health Organization (WHO), an individual is considered to have low vision if the visual acuity with optical correction in the better eye is $<20 / 70(0.3)$ and $>20 / 400(0.05)$ or if the visual field is less than $20^{\circ}$ in the better eye with the best optical correction possible ${ }^{(3)}$.

Low vision is characterized by a significant change in the functional capacity of vision that results in isolation and is caused by a single or multiple factors such as significant visual impairment, a significant decrease in the visual field, and changes in color vision and/or contrast sensitivity that interfere with or limit visual performance ${ }^{(4)}$. It also can be described as any degree of visual impairment that causes disability and a decrease in visual performance ${ }^{(5)}$.

While performing activities of daily living, there is a need to utilize reading and writing; these activities can be greatly affected by visual loss because the eyes are necessary to perform these.

Improvement in the visual performance of an individual with low vision can be achieved through the use of resources such as assistive technology. Assistive technology is an interdisciplinary area of knowledge that includes products, resources, methodologies, strategies, practices, and services that work to promote the functionality related to the activity and participation of individuals with disabilities, inabilities, or decreased mobility, and it can help those that are seeking autonomy, independence, quality of life, and social inclusion ${ }^{(6)}$.

Assistive technology resources may be optical, nonoptical, or electronic. These resources can lead to a decrease in functional losses in patients with low vision ${ }^{(7)}$. 
Optical aids include one or more lenses that are placed between the eyes and the object to promote the magnification or enlargement of the retinal image. The optical aids can be as simple as a glass lens to better see the details of a figure or as complex as a sophisticated telescope that can be used for far and near vision ${ }^{(8)}$.

Nonoptical aids are simple features that can increase visual resolution. These features do not involve the use of a magnifying lens to improve visual function, but they can be used in addition to optical devices or may possibly replace them in some instances. Some examples include filter lenses, lighting, marker pens, magnification of materials, and changes in contrast (dark background and light object) ${ }^{(5)}$.

Language is a way to communicate and express feelings, ideas, and actions. It is a process of dialogue that takes place in the social practices of different groups at different times in their history and an activity and a mental operation that involves the construction of meaning ${ }^{(9)}$.

This emphasizes the importance of the use of optical and nonoptical aids to help individuals with low vision in performing reading and writing activities.

This study aimed to verify the use of optical and nonoptical aids to assist in the performance of reading and writing activities by individuals with low vision.

\section{METHODS}

This was a descriptive and cross-sectional study. To construct the data collection instrument, we used features of exploratory research that presented qualitative and contextual results ${ }^{(10)}$.

The population comprised 30 subjects with acquired low vision who attended the Rehabilitation Program for Adolescents and Adults with Visual Impairment conducted by the Center of Studies and Researches in Rehabilitation (CEPRE), College of Medical Sciences (FCM), University of Campinas (UNICAMP), Brazil. The inclusion criteria were as follows: subjects aged $>18$ years who were divided into young adults (18-39 years), adults (40-59 years), and elderly (>60 years); literacy; acquired low vision; and participation in the Rehabilitation Group of CEPRE during the period between June and December 2008.

The variables selected were personal characteristics, the use of optical and nonoptical aids, and participation in activities that required the use of optical and nonoptical aids.

The data collection instrument was created using structured questions developed from an exploratory study, a previous test based on interviews, and reading and writing activities associated with the use of optical and nonoptical aids.

During the planning stage, this study provided data that reflected the knowledge and opinions of individuals with acquired low vision with regard to reading and writing activities. Therefore, it was possible to adjust the perceptions of the researcher to match the perceptions of the subjects.

The first phase of the exploratory study involved individual interviews with 3 subjects with acquired low vision, which included open questions based on the above variables, and reading and writing activities.

On the basis of the results obtained in the first exploratory stage, the second phase involved the construction of a semistructured measuring instrument. The questions were organized to respect the order of content and grouped according to the study variables, while maintaining fidelity to the language used by the subjects. With the data obtained in this second phase, it was possible to build the instrument with structured questions.

The previous test was intended to improve the instrument and gradually integrate stepwise information into the exploratory study. Proof was needed to ensure the reliability and validity of data obtained during the research ${ }^{(11)}$.
The previous test was performed by applying the structured questionnaire to 3 subjects with acquired low vision who had not participated in the previous steps (the third phase of the exploratory study). At the end of this phase, the questions in the quiz needed to be reviewed and answered.

The researchers applied the previous test to subjects with low vision included in CEPRE. This population was similar to the population that was involved in the exploratory study, which was excluded from the final population.

The fourth and final stage of the exploratory study was completed by re-applying the questionnaire to 2 other subjects with acquired low vision. No changes were required; therefore, the instrument for data collection was complete.

Data collection was performed using the structured questionnaire administered to subjects who agreed to participate in the study by signing an informed consent statement.

After collecting the data, the open questions were categorized and grouped and the closed questions were quantified and tabulated. The responses were statistically analyzed using EPI INFO version 6.0.

\section{RESULTS}

The study population comprised 30 subjects with acquired low vision and visual acuities of 20/80-20/1000. All subjects were considered to have severe visual impairment, and $60 \%$ were males. The age range was 18-73 years, with an average age of 38 years.

With regard to educational qualification, $33.5 \%$ subjects had received primary education, $23.3 \%$ had completed elementary school, $20.0 \%$ had completed secondary school, $16.6 \%$ had completed high school, and $6.6 \%$ had received university education.

The age of onset of the eye problems ranged from 10 to 69 years, and the average age of onset was 29 years. The duration of participation in the Group Rehabilitation CEPRE ranged from 1 to 8 months, with an average duration of 4.5 months.

Table 1 shows that the majority (60.0\%) of subjects reported the use of some optical aids. Of this $60.0 \%$, the majority (83.3\%) cited that lenses (regular spectacles) were the most commonly used. It also shows the activities during which the subjects used these optical aids, highlighting the activities of reading, cleaning, cooking, and shopping (50.0\%).

\begin{tabular}{lcc}
$\begin{array}{l}\text { Table 1. Use of optical aids by subjects included in the } \\
\text { rehabilitation program for adolescents and adults with }\end{array}$ \\
visual impairment (CEPRE-FCM-UNICAMP; Campinas, 2008) \\
\hline Optical aids & N & \% \\
\hline & 18 & 60.0 \\
Declare use & 12 & 40.0 \\
Claim ignorance & & $\mathrm{N}=18$ \\
Types of optical aids* & 15 & 83.3 \\
Spectacles & 4 & 22.1 \\
Telescope system & 1 & 5.3 \\
Manual magnifier & 1 & 5.3 \\
Sun glasses & & $\mathrm{N}=18$ \\
Activities using optical aids* & 9 & 50.0 \\
Reading & 9 & 50.0 \\
Cleaning, cooking, shopping & 9 & 27.7 \\
Watching TV & 5 & 5.3 \\
Writing & 1 & 5.3 \\
Orientation and mobility & 1 & \\
\hline
\end{tabular}

${ }^{*}=$ multiple answers.

$\mathrm{N}=$ number of subjects; $\%=$ percent 
Table 2 shows that the majority (63.3\%) of subjects reported the use of nonoptical aids. The most frequent nonoptical aids were letter magnification (68.4\%), followed by bringing objects closer to the eyes (57.8\%). The subjects often used more than one nonoptical aid.

The activities during which the participants reported the use of nonoptical aids have been listed In table 2, including reading (73.6\%), writing (21.0\%), and watching television (10.5\%).

Table 3 shows that the majority (55.5\%) of subjects used optical aids for easier reading. The most common aids used were spectacles (90.0\%), followed by manual magnifying lenses (10.0\%).

\section{DISCUSSION}

The study of the characteristics of visual impairment, featuring individuals with blindness or low vision and their opinions and expectations during the rehabilitation process, is fundamental to planning their rehabilitation and making it compatible with the patient's condition ${ }^{(11)}$

Researchers believe that the cognitive science of reading and writing has much to contribute to research in the field of visual impairment because both reading and writing utilize the eyes ${ }^{(12)}$.

\begin{tabular}{|c|c|c|}
\hline Nonoptical Aids & $\mathbf{N}$ & $\%$ \\
\hline & & $N=30$ \\
\hline Declare use & 19 & 63.3 \\
\hline Claim ignorance & 11 & 37.6 \\
\hline Types of nonoptical aids* & & $N=19$ \\
\hline Letter magnification & 13 & 83.3 \\
\hline Bring the objects closer to the eyes & 11 & 58.0 \\
\hline Lighting & 6 & 31.5 \\
\hline Telescope & 4 & 21.0 \\
\hline Contrast & 3 & 15.7 \\
\hline Support for reading and writing & 1 & 5.3 \\
\hline Activities using nonoptical aids* & & $N=19$ \\
\hline Reading & 14 & 73.6 \\
\hline Writing & 4 & 21.0 \\
\hline Watch TV & 2 & 10.5 \\
\hline Computer use & 1 & 5.3 \\
\hline Crochet, sewing & 1 & 5.3 \\
\hline
\end{tabular}

* = multiple answers.

$\mathrm{N}=$ number of subjects; $\%=$ percent

Table 3. Use of optical aids for easier reading by subjects included in the rehabilitation program for adolescents and adults with visual impairment (CEPRE-FCM-UNICAMP. Campinas-SP, 2008)

\begin{tabular}{lcc}
\hline Optical aids & N & $\%$ \\
\hline & & $\mathrm{N}=18$ \\
Use & 10 & 55.5 \\
No use & 8 & 44.5 \\
Type of optical aids* & & $\mathrm{N}=10$ \\
$\quad$ Spectacles & 9 & 90.0 \\
$\quad$ Handheld magnifier & 1 & 10.0 \\
\hline
\end{tabular}

* = multiple answers

$\mathrm{N}=$ number of subjects; $\%=$ percent
This study verified that the prevalence of low vision was greater among men (60.0\%) than among women. Other authors have also found larger populations of men with low vision ${ }^{(13,14)}$.

The age of onset of visual impairment varied between 10 and 69 years in this study, with the mean age of onset being 29 years. In a study by Montilha ${ }^{(15)}$ conducted in CEPRE/FCM/UNICAMP the mean age of patients was 27.9 years, which was close to that in our study. Both studies were conducted in CEPRE; this probably affected the age of the populations.

Most subjects (60.0\%) reported the use of some optical aids to perform near and far activities, and the activities that were most often cited were reading, cleaning, cooking, and shopping. Of those $60.0 \%$, the majority (88.8\%) reported the use of spectacles and lenses to perform close manual activities (Table 1). Carvalho et al. ${ }^{(16)}$ reported similar findings in their study, where $60 \%$ subjects reported the use of optical aids. These patients achieved considerable improvement in visual acuity when they used prescriptions for near distance vision in accordance with their visual needs.

Spectacles allow for better vision during near tasks by providing a greater visual field, thus facilitating the performance of activities of daily living (ADL) and ambient visual processing (AVP). Telescope systems can assist with distance tasks such as watching television, orientation, mobility and shopping, locating industries and stores, and finding boxes. Manual loupes are designed to help subjects with low vision to perform close, short-term tasks.

The selection of such aids is based on the patient's visual status and the visual and activity needs of the individual with low vision. After the selection of optical aids, adaptation is very important. If the patient is trained, the aids will be used appropriately ${ }^{(17)}$.

For the activities of cleaning and cooking, the manual magnifying glass can be used to identify a product or a food; however, the subject would need to be careful when approaching the stove for safety.

According to Bonatti el al. ${ }^{(18)}$, optical aids can assist and improve the vision quality in subjects and can make the more commonly performed activities (reading, cleaning, cooking, shopping) easier. The findings of these authors agreed with those of our research; reading, cleaning, cooking, and shopping (50.0\%) were cited as the activities during which the subjects used optical aids. In this study, we also determined that the use of optical aids made it easier to perform such activities.

Overall, the experiences with daily life activities showed that most subjects with visual impairment experienced difficulties before the visual practice of ADL/AVPs. The use of optical aids is effective in conducting these activities and can improve the visual performance of subjects with their use.

To facilitate and promote the frequent use of optical aids, subjects should always use them for tasks; the periods of use must be serialized and short in order to avoid visual and physical fatigue. It is important for the physician or the rehabilitation team to explain the purposes of the aids to enable the patient to make the best use of his or her residual vision ${ }^{(16)}$.

Sacks ${ }^{(19)}$ mentioned that the use of optical aids can increase the self-esteem of subjects with low vision. The benefits of using these aids include the development of a sense of independence (when the subject can have access to reading materials printed in the daily environment, he or she becomes independent), an increase in the sense of responsibility (in purchasing real visual information, he or she realizes their potential and feels safe and responsible in other situations), an improvement in identification of the environment, the development of a sense of competence (because the subject has visual control over the environment), and the feeling of great pleasure with their vision quality.

The use of optical aids does more than improving visual function. It also impacts the emotional side of the subject. This is very important for effective participation in the rehabilitation process and can improve the quality of life and social inclusion. The use of optical aids allows patients to use their residual vision and preserve their visual function ${ }^{(16)}$ 
In a study, conducted in rehabilitation programs, that determined rehabilitation strategies that were most suitable for each subject, Lucas et al. ${ }^{(15)}$ found that the most frequent goal of the use of optical aids was to improve performance of reading and writing activities (44.5\%).

The prescription of optical aids depends to the subject's visual status and can generally improve visual performance, depending on the eye disease, level of visual acuity, and beliefs of the subject in relation to eye health. A study conducted in England showed the follow-up of 168 patients who were prescribed optical aids for low vision, received orientation for the use of nonoptical aids, and were followed for 6 consecutive months. The level of performance in their reading activities improved significantly, with $88.0 \%$ subjects beginning to read letters printed in newspapers after receiving the treatment mentioned ${ }^{(20)}$.

Most (63.3\%) subjects in this study reported the use of nonoptical aids. The nonoptical aids most frequently used were letter magnification (68.4\%), followed by bringing the objects closer to the eyes (57.8\%). Reading activities (73.6\%) were the most frequently mentioned activities during which nonoptical aids were used, followed by writing activities (21.0\%; Table 2 ).

The nonoptical aids mentioned in this study (magnification, bringing the object closer to the eyes, lighting, telescope systems, contrast, support for reading and writing) were largely used for the most frequently cited activities of reading and writing. Nonoptical aids are easy to use; however, some can be expensive. These aids were available for most subjects who participated in this study.

Nonoptical aids can be used alone or in conjunction with optical aids in order to promote the best adaptation and functional use ${ }^{(21)}$. As a matter of fact, the combination used is often indicated in activities such as reading and writing because the use of all available resources can make it easier for the subject ${ }^{(22)}$.

Table 1 shows that $60 \%$ subjects reported the use of optical aids for these activities. Of these, 55.5\% reported the use of these aids for easier reading. Of the $55.5 \%$ who used optical aids for easier reading, $90.0 \%$ reported the use of spectacles and $10.0 \%$ reported the use of manual magnifiers.

The spectacles are used with a high frequency because of their convenience. After placing them on the face, the subject needs to find the best position for reading; spectacles can also be used in conjunction with nonoptical aids. With aids such as manual magnifying lenses, the speed of reading can be slowed down because the subject can explore only a small piece of text at a time; the subject also has to use one hand to hold the lens itself(22). With handheld magnifiers, the subject needs to do two things at the same time: hold the handheld magnifier and focus the eyes on what he or she is reading.

Reading involves the integration of multiple factors such as the previous experience of the subject, skill, and neurological functioning. During reading, different eye movements are required; the saccades that bring the eyes from left to right and the oblique saccades that lead the eye from one line of the text to the next. Additionally, the angle of vergence of the two optical axes must be adjusted to the distance from the reading material(23).

According to Cagliari(24), the skill of writing in adults is so integrated into everyday life that most of the time, its importance and usefulness in life maintenance and survival may not be recognized. In a world built by the written word, individuals who can see may not reflect on the difficulties faced by individuals with visual impairments who are exposed daily to reading and writing tasks.

It was found that, despite the use of nonoptical aids by all subjects during writing activities, they reported the use of letter magnification and bringing the objects closer to their eyes to better perform their activities (Table 2). Individuals with low vision can write even without the use of optical and nonoptical aids, although they most often do not read what they write. This difficulty can be minimized by the use of nonoptical aids such as the expansion of (own) words and bringing objects closer to the eyes.

The most important way to acquire knowledge, even during this era of the internet and in this virtual world, is still the written language. Reading and writing is an essential requirement for an individual to participate effectively in the society they live in and to be a conscientious citizen.

\section{CONCLUSIONS}

The majority of subjects reported the use of optical and nonoptical aids during reading activities and highlighted the use of spectacles, magnifying lenses, and the manual expansion of words.

To perform the activities of writing, all subjects reported the use of optical aids, while most said that they did not use nonoptical aids during such activities

Even while using these aids, it was found that the subjects needed to read the text more than once to understand it.

\section{REFERENCES}

1. Sanches PA. Deficiências visuales y psicomotricidade: teoria y pratica. Organización Nacional de Ciegos Españoles. 1994. p.255.

2. Alves MR, Kara-Jose N. O olho e a visão: o que fazer pela saúde ocular das nossas crianças. Rio de Janeiro: Vozes; 1996.

3. World Health Organization. Consultation on development of standards for characterization for vision loss and visual functioning [Internet]. Geneva: WHO/PBL; 2003. [cited 2013 Dec 21]. Available from: http://whqlibdoc.who.int/hq/2003/WHO_PBL_03.91.pdf?ua=1

4. Bruno MM. A inclusão da criança com baixa visão na educação infantil. In: Masini EF Gasparetto ME. Visão subnormal: um enfoque educacional. São Paulo:Vetor; 2007. p.84

5. Montilha RC, Temporini ER, Nobre MI, Gasparetto ME, Kara-Jose N. Utilização de recursos ópticos e equipamentos por escolares com deficiência visual. Arq Bras Oftalmol. 2006:69(2):207-11.

6. Brasil. Ministério da Justiça. CORDE. Comitê de Ajudas Técnicas. Ata VII. Brasília: MJ. [citado 2009 Ago 5]. Disponível em: http://www.mj.gov.br/sedh/ct/corde/dpdh/ corde/comite_at.asp

7. Brito PR, Veitzman S. Causas de cegueira e baixa visão em craianças. Arq Bras Oftalmol. 2000:63(1):49-54.

8. Thylefors B, Négrel AD, Pararajasegaram R, Dadzie Ky. Global date on blindness. Bul World Health Organ. 1995;73(1):115-20.

9. Oliveira LL. Uma possibilidade de intervenção psicopedagógica no processo dialético de mediação entre o sujeito que aprende e o objeto do conhecimento. In: Santos MT, Navas AL. Distúrbios de leitura e escrita: teoria e prática. São Paulo: Manole; 2002. p.169-90.

10. Piovesan A, Temporini ER. Pesquisa exploratória: procedimento metodológico para o estudo de fatores humanos no campo da saúde pública. Rev Saúde Pública. 1995; 29(4):318-25.

11. Temporini ER. Pesquisa de oftalmologia em saúde pública: considerações metodológicas sobre fatores humanos. Arq Bras Oftalmol. 1991;54(6):279-81.

12. Corn Al, Wall RS, Jose RT, Bell JK, Wilcox K, Perez A. An initial study of reading and comprehension rates for students who received optical devices. J Vis Impair Blind. 2002;96(5):322-33.

13. Montilha RC. O atendimento de terapia ocupacional com o adulto portador de cegueira adquirida. Sinopse de Oftalmologia. 2000;2(1):24-5

14. Lucas MB, Leal MO, Tavares SS, Barros EA, Aranha ST. Condutas reabilitacionais em pacientes com baixa visão. Arq Bras Oftalmol. 2003;66(1): 77-82

15. Montilha RC, Temporini ER, Kara-Jose N, Nobre MI. Deficiência visual: características e expectativas da clientela de serviço de reabilitação. Rev Ciênc Méd (Campinas). 2000;9(3):123-8.

16. Carvalho KM, Monteiro GB, Isaac CR, Shiroma LO, Amaral MS. Causes of low vision and use of optical aids in the elderly. Rev Hosp Clin Fac Med Sao Paulo. 2004;59(4):157-60.

17. Burman-Lindelow P. Magnificação e auxílios ópticos em baixa visão. In: Veitzman S Visão subnormal. Rio de Janeiro, Cultura Médica; 2000. p.111-22.

18. Bonatti FAS, Bonatti JA, Sampaio MW, Haddad MA, Souza PR, Kara-Jose N. [Evaluation of patients using an innovative low-vison aid]. Arq Bras Oftalmol. 2008;71(3):385-8. Portuguese.

19. Sacks SZ. Psychological and social implications of low vision. In: Corn AL, Koenig AJ. Foundation of low vision: clinical and functional perspective. New York: American Foundation for the Blind press; 1966. p.26-42.

20. Margrain TH. Helping blind and partially sighted people to read: the effectiveness of low vision aids. Br J Ophthalmol. 2000;84(8):919-21.

21. Haddad MAO, Sampaio MW. Estudo da acuidade visual e da velocidade de leitura na baixa visão. In: Sampaio MW, Haddad MA, Filho HA, Siaulys MO, organizadores. Baixa visão e cegueira: os caminhos para a reabilitação, a educação e a inclusão. Rio de Janeiro: Cultura Médica; 2010. p.79-96

22. Monteiro MM, Montilha RC, Gasparetto ME. Atenção fonoaudiológica e a linguagem escrita de pessoa com baixa visão: estudo exploratório. Rev Bras Educ Esp. 2011;17(1):121-36.

23. Castro CT. Método de avaliação da acuidade e velocidade de leitura-Tabela MNREAD. In: Ventura OL, Travassos SB, Silva AO, Dolan MA. Dislexia e distúrbios de Aprendizagem. Rio de janeiro: Cultura Medica; 2012. p.175-82.

24. Cagliari CL. Alfabetização \& Lingüística. 10a ed. São Paulo: Sapione; 2001 